\title{
elyra
}

\section{Ouvir o que vem vindo (sem nunca terminar de chegar): escuta e ilegibilidade em Nuno Ramos}

\author{
Rafaela Scardino \\ Universidade Federal do Espírito Santo
}

Resumo: Qual o regime de sentidos que se mobiliza quando escutamos um texto? Quais são as diferenças, as interpolações, os tempos que ressoam quando escutamos um texto sem poder lê-lo? Jean-Luc Nancy propõe que a escuta é sempre ressonância - é sempre relação, portanto. Em Monólogo para um cachorro morto, produção multimídia do artista plástico e escritor Nuno Ramos, um aparelho de som reproduz um texto falado para um cachorro morto. À escuta é suprimido o vivente: resta a máquina que reproduz um texto para um corpo já desprovido de qualquer reação. A nós, "espectadores", resta o registro em vídeo da máquina que fala para o ser inerte. Também escutamos, talvez envoltos num voyeurismo não de todo repelido, esse texto que não nos é dirigido. Estamos à escuta desse texto, e em nós ele ressoa, ainda que de viés. A ressonância da escuta, escreve Nancy, "põe em jogo todo o regime dos sentidos". E ainda: "talvez seja preciso que o sentido não se conforme com fazer sentido (ou ser logos), mas que também ressoe". O corpo-fenda que nasce da ressonância entre homem e cachorro cria um espaço de indiscernibilidade entre os dois. O vivente passa a ser confrontado pela presença desse outro que ressoa nele à sua revelia, pois atravessa o limite da consciência para encontrá-lo lá onde não poderá erigir uma separação.

Palavras-chave: 1. Escuta; 2. Ilegibilidade; 3. Comunidade; 4. Performance

Abstract: What regimen of senses is mobilized when we listen to a text? What are the differences, the interpolations, the multiple times that resonate when we hear a text without being able to read it? Jean-Luc Nancy proposes that listening is always resonance - it is always a form of being in a relation with one another, and the world. In Monologue for a dead dog, a multimedia production by the visual artist and writer Nuno Ramos, a stereo reproduces a spoken text for a dead dog. To the act of listening, is suppressed the living being: there remains the machine that reproduces a text for a body already devoid of any reaction. We, the "spectators", are the ones left with the possible senses/meanings of this text that is not meant for us. We are 
listening to this text, and it resounds in our bodies. The resonance of listening, writes Nancy, "puts the whole regimen of the senses into question." In addition, the philosopher continues: "Perhaps the sense must not be satisfied with just making sense (or being logos), but also with resounding." The fissured body that is born from the resonance between man and dog creates a space of indiscernibility between the two. The living being is confronted by the presence of this other being that resounds in him albeit his will, for this body-image crosses the limit of consciousness to find the living person where one cannot erect a separation through legibility.

Keywords: 1 . Listening; 2. Illegibility; 3. Community; 4. Performance

A comunidade sem comunidade é um por vir, no sentido que sempre está vindo, sem parar, ao seio de uma coletividade (é porque não deixa de vir que resiste sem fim à própria coletividade e ao indivíduo). É apenas isso: chegar ao limite do comparecimento, a este limite ao que estamos com efeito convocados, chamados e enviados - e desde onde somos convocados, chamados e enviados. O chamado que nos convoca, assim como o que nos dirigimos, no limite, uns aos outros (é, sem dúvida, de um a outro, o mesmo chamado, e não é o mesmo) pode denominar-se, na falta de outro nome melhor, a escritura, ou a literatura.

Jean-Luc Nancy, A comunidade inoperante

"Poesia (pausa), entre nós dois" (Ramos 2007: 359). Jean-Luc Nancy propõe que a escuta é sempre ressonância - é sempre relação, portanto. Em Monólogo para um cachorro morto, produção multimídia de Nuno Ramos, um aparelho de som reproduz um texto falado para um cachorro morto. À escuta é suprimido o vivente: resta a máquina que reproduz um texto para um corpo já desprovido de qualquer reação. A nós - que, de algum modo, estabelecemos contato com a instalação - , resta o registro em vídeo da máquina que fala para o ser inerte. Também escutamos, talvez às voltas com um voyeurismo não de todo repelido, esse texto que não nos é dirigido. Estamos à escuta desse texto, e em nós ele 
ressoa, ainda que de viés. Entre o homem (vivo) e o cachorro (morto), poesia. Entre quem assiste/ouve e o possível sentido do texto, a voz de Nuno Ramos, o barulho dos carros na rodovia, a visão incessante do cachorro morto.

A instalação se organiza em dez enormes lâminas de mármore branco, dispostas em duas fileiras de cinco peças, com um espaço iluminado de $20 \mathrm{~cm}$ entre elas. Em cinco dessas "lápides" o texto reproduzido no vídeo está esculpido em baixo-relevo, mas a proximidade da "lápide" que compõe a segunda fileira não permite a leitura. Assim, novamente, só nos cabe escutar o texto, como o cachorro morto, o guard-rail, a rodovia onde permanece o corpo do animal. O monitor que exibe o vídeo está fixado numa das "lápides" sem texto, vazia. Não há epitáfio, há confissão. Colocamo-nos (somos colocadas e colocados) na posição de quem ouve uma confissão vendo um corpo que deveria estar oculto sob as lápides. Estas, no entanto, ocultam o texto, que tem algo do desespero daqueles que esperam um diálogo que não virá.

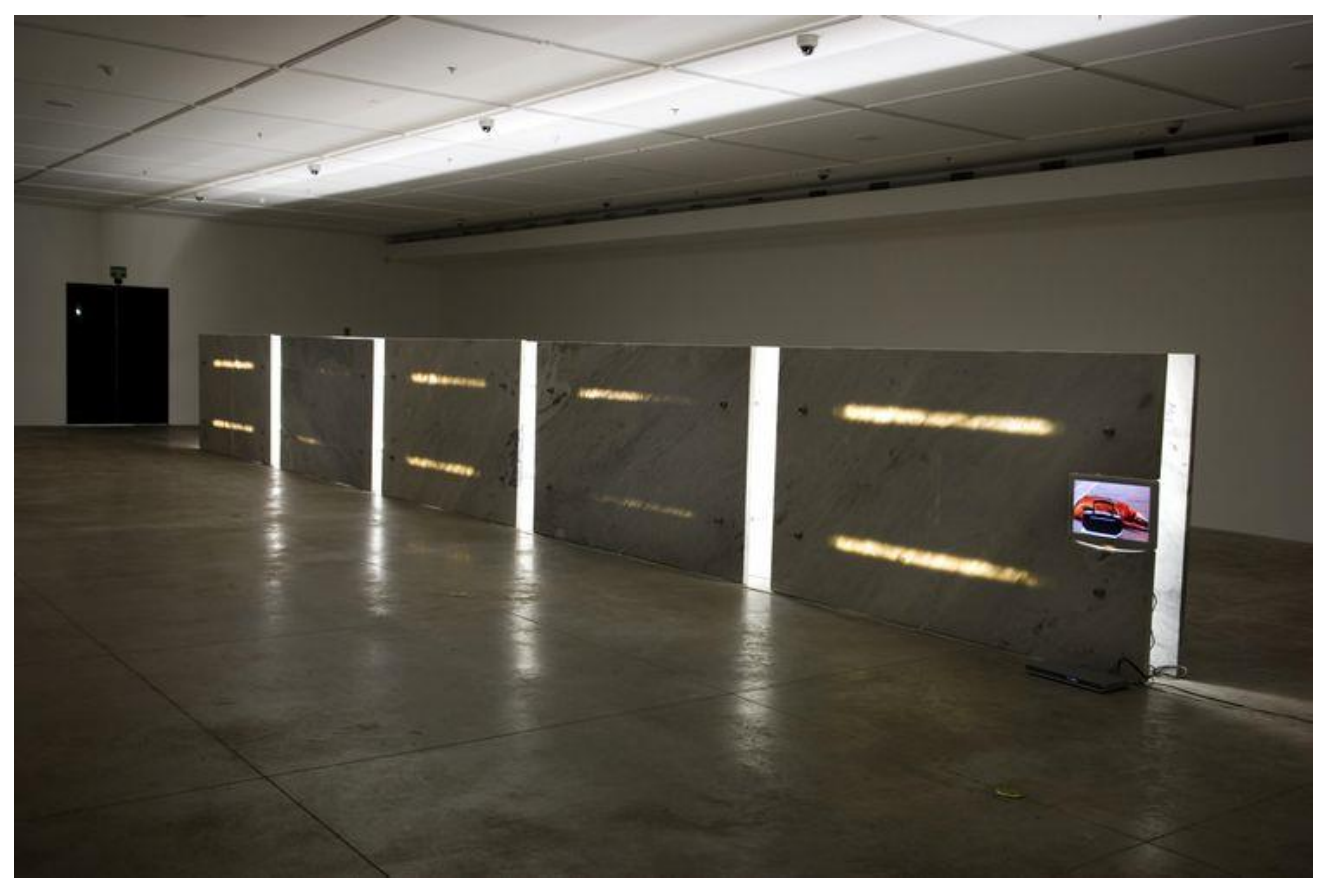

Figura 1. Fonte: www.nunoramos.com.br 


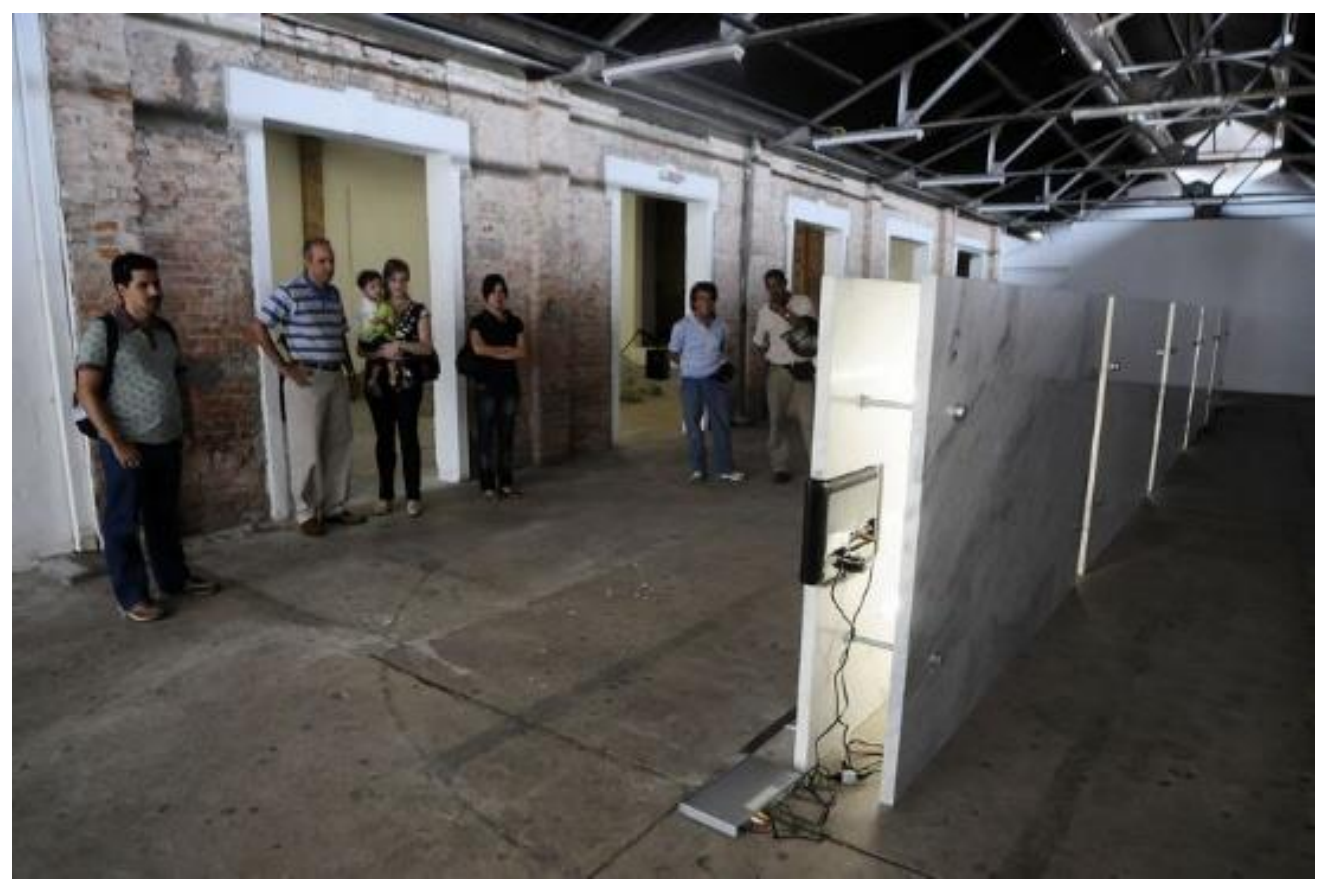

Figura 2. Fonte: www.nunoramos.com.br

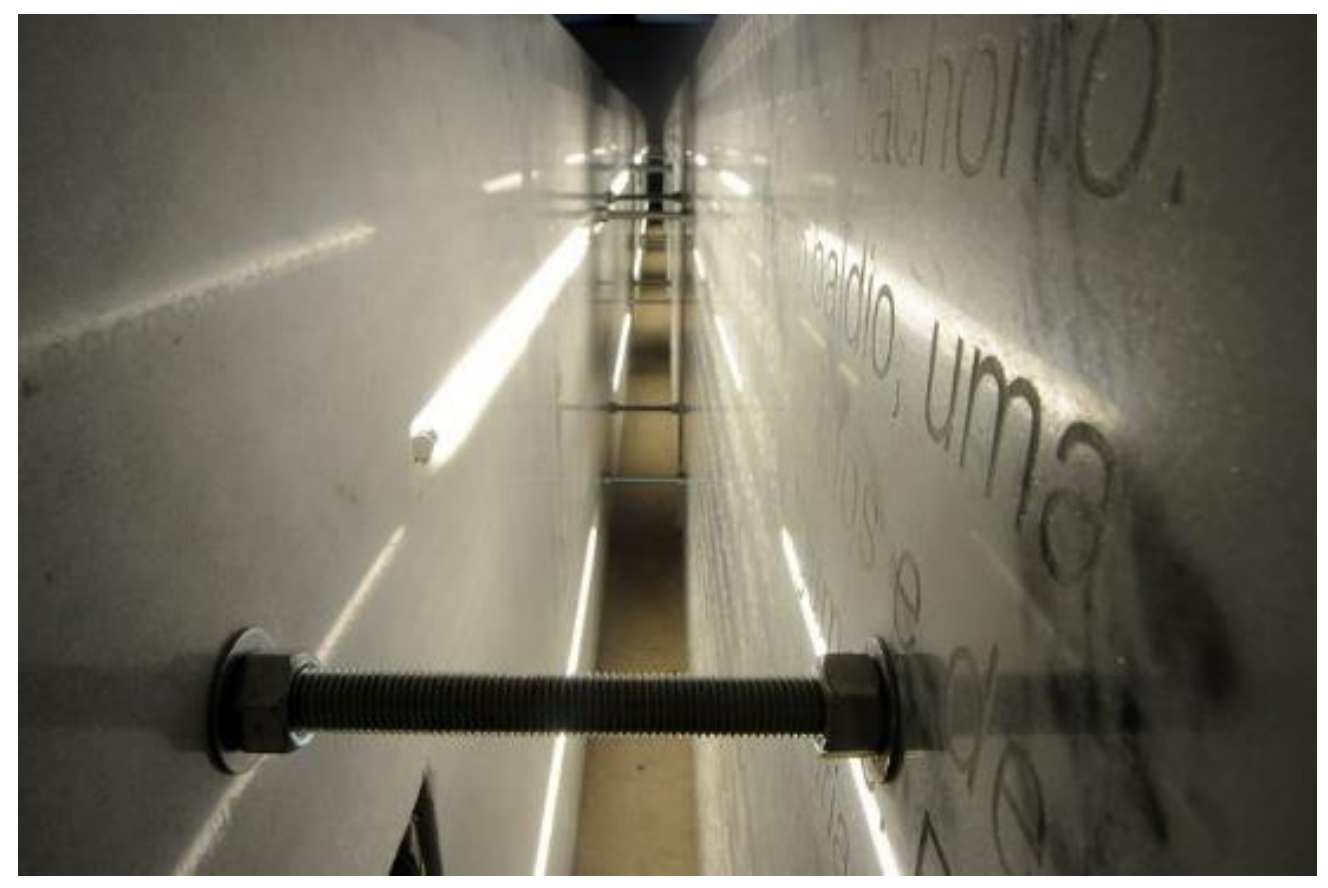

Figura 3. Fonte: www.nunoramos.com.br 
O que resta de uma vida - vida humana, vida qualificada - traduz-se, muitas vezes, num texto. A lápide esconde o corpo e dá a ver o texto, o logos, que o substitui. Aquele que vê a lápide está apartado da falta de decoro do corpo em decomposição. Do corpo-fenda que permite que "um terceiro corpo [nasça] deles, entre eles, feito de" (Ramos 2007: 359). Ao cachorro é negado o decoro da lápide, do logos que se interpõe entre o morto e o vivente. Somos expostos a seu corpo morto, já desfigurado, "carranca", sem poder conterIhe num sentido, num texto, que nos proveja qualquer conforto.

A ressonância da escuta, escreve Nancy, "põe em jogo todo o regime dos sentidos" (Nancy 2007: 13). E ainda: "talvez seja preciso que o sentido não se conforme com fazer sentido (ou ser logos), mas que também ressoe" (idem: 18). O corpo-fenda que nasce da ressonância entre homem e cachorro cria um espaço de indiscernibilidade entre os dois. 0 vivente passa a ser confrontado pela presença desse outro que ressoa nele à sua revelia, pois atravessa o limite da consciência para encontrá-lo lá onde não poderá erigir uma separação - uma lápide, um texto, um sentido:

\footnotetext{
Não canso de te encontrar onde não quero, dentro das minhas coisas, dentro de certas palavras, numa alegria súbita, no formato de uma nuvem, no gosto da saliva de outra pessoa, que beijei e bebi. Por que não largo você? Por que não abro as pálpebras e solto a tua imagem? Imagem, matilha aprisionada - saia daqui. Saia de trás das minhas pálpebras. Não te guardo mais. Flutue até que a próxima chuva te encharque, até que o excesso de luminosidade te apague. Vire corpo, imagem. Vire corpo completamente [...] (idem: 360)
}

Poderíamos pensar, então, numa ilegibilidade constituinte dessa relação. Não é possível interpor, entre homem e animal, um texto, um sistema de legibilidade exclusivamente humano. Não é possível antepor ao sentido enquanto sensação - enquanto visão, olfato, audição que invade o corpo aberto daquele que fala, que ressoa - o que Nancy chamará de o "sentido sensato", o logos, o que se pode ler. Porque o corpo animal interrompe tal ordenação do real e se inscreve naquilo que ressoa, que instaura o ser na relação com o si mesmo; aquilo que ressoa, ou seja, que soa a partir daquele que fala, mas também dentro dele.

Gabriel Giorgi afirma que a vida animal "desafia pressupostos sobre a especificidade e a essência do humano, e desbarata sua forma mesma a partir de uma instabilidade 
figurativa que problematiza a definição do humano como evidência e como ontologia" (Giorgi 2016: 12). Daí o pedido daquele que fala para que esse cachorro-imagem se torno corpo: que volte a ser animalidade, que volte a ser aquilo que se lê como o oposto do humano e que, portanto, Ihe define e Ihe confere limite e especificidade.

Pois o corpo-fenda que se instaura nesse encontro, nessa ressonância, é inespecífico e ilegível. Já não se adequa a formas consabidas de legibilidade. Já não se define pelas relações de pertencimento ou de exclusão que o identificavam enquanto específico. Mas é justamente nessa ilegibilidade, nessa inespecificidade que se poderá criar um espaço outro, espaço intervalar, em que os corpos poderão ressoar entre si, pondo em jogo o regime do sentido, ou seja, do logos. E nesse espaço de ilegibilidade, sem identificação que subjuga as singularidades, será possível, será necessário, instaurar uma comunidade ilegível, ou melhor: tal ilegibilidade será a condição de uma comunidade sempre em devir, que nunca torne obra sua potência.

Diante dessa ressonância, dessa comunidade ilegível que se instaura entre homem e cachorro, cabe perguntar: qual é (quais são) o(s) sentido(s), se o(s) há, de um monólogo para um cachorro morto? O que poderá ressoar desse sentido que se/nos propõe ir além do logos?

A exposição aqui discutida faz parte de um projeto de longa duração, que além da já comentada instalação, gerou outro projeto de exposição, "Monólogo para um tronco podre" (que ainda não se realizou em obra), e o livro de poemas com fotografias Junco. Os textos dos dois projetos de exposição foram publicados no livro Ensaio geral e o áudio, o vídeo e o texto que compõem a exposição Monólogo para um cachorro morto, bem como fotos do trabalho, estão disponíveis no site do artista. Assim, respondendo à pergunta que coloquei anteriormente - o que pode ressoar dessa fala, dessa voz - , me parece que a resposta é a própria palavra literária, o contínuo questionamento poético sobre os limites da singularidade dessas existências a princípio tão díspares: homem vivo, cachorro morto, tronco podre. Voltando às palavras de Jean-Luc Nancy: "escutar é estar voltado para um sentido possível e, em consequência, não imediatamente acessível" (Nancy 2007: 18). Quer dizer, o texto poético, o texto para o cachorro morto, para o tronco podre, ressoa, em 
diversas frequências, em nós, que lemos/assistimos/ouvimos: enfim, que somos expostas e expostos a ele.

A comunidade, como propõe Jean-Luc Nancy em A comunidade inoperante, é aquilo que nos apresenta uma existência fora de nós-mesmos, composta por seres finitos que só se (re)conhecem nos limites de sua finitude, nos limites do si-mesmo que indicam a borda, o corpo-fenda, que faz ressoar o outro. A comunidade é uma comunidade da finitude porque nenhuma outra coisa é comunitária: no fim, no limite do eu, estou exposta ao outro.

A saída do eu é, também, a saída de um relacionamento com a linguagem que cria margens, contornos e zonas de separação ao nomear os seres e as coisas. O nome contém um limite, uma definição e uma identificação que impedem a ressonância inespecífica. Nesse sentido, a voz que lê o Monólogo encontra a alegria na perda dos nomes:

[...] mas não sei, alegremente não sei o nome de mais nada, nem de ninguém. Esqueci todos eles. [...] estive ali mas esqueci completamente o nome do que fiz, dos produtos e das pessoas e dos lugares, das ruas e avenidas onde estavam. Esqueci, como um milagre. Esqueci tudo, alegre e absolutamente tudo, e me debrucei sobre você [...] (Ramos 2007: 361)

A saída da contenção do nome coincide com o aceitar habitar o espaço-entre inaugurado pelo corpo-fenda que já não teme a exposição ao outro, que se debruça sobre a finitude, como que a encará-la e a aceitá-la como parte fundamental do encontro de singularidades que the permite o encontro com o cachorro.

Um corpo-fenda que, "trazendo no bolso um pequeno pedaço do sabonete gigantesco em que você [cachorro] se transformará" (ibidem), desloca-se em direção ao outro, propõe a encontrá-lo na brecha, na falha, na finitude. Porque o sabão é o que rompe com a tensão superficial que separa a água daquilo que se pretende molhar. De alguma forma, o sabão instaura a fenda. E é também precário, porque se dissolve em contato com a água. O contato, o encontro, não é soma. O sabão se dissolve, perde sua materialidade, não soma, não adiciona, mas se deixa ir no contato. Assim como no encontro entre homem e cachorro não há soma de corpos, mas instauração de um espaço - espaço vazio - em que a fenda permite o contato, permite molhar, ou seja, permite que, do contato, nosso próprio estado mude, que nos contaminemos. 
No entanto, nesse encontro, nessa ex-posição, aquele que diz eu no Monólogo para um cachorro morto, ainda que reconhecendo-se no limite do outro, o cachorro, ao questionar-se sobre seu próprio fim, volta a solicitar um nome:

\begin{abstract}
Cachorro, você faria o mesmo? Faria o mesmo que eu fiz? Faria o mesmo por mim? Incendiaria meu corpo num barranco, num chão com folhas de mamona? Cobriria meus olhos com dois girassóis enormes e botaria fogo? Colheria as minhas cinzas cuidadosamente? Cachorro? E quando reclamassem meu corpo, a família e os amigos enlutados reclamassem meu corpo, como descobriria meu nome? Que nome daria a eles? Que nome você daria? Qual o meu nome, cachorro? (idem: 362)
\end{abstract}

Num encontro de singularidades não individualizadas - cuja marca é a ausência do nome -, o eu pergunta àquele outro ser singular, no qual encontra a ressonância da finitude, por uma identidade. Há aqui um processo que se desdobra em dois: o reconhecimento de que apenas no limiar da vida - e também do humano, pode-se acrescentar - um ser singular pode reconhecer-se, ou ressoar, em outro; mas há, ainda, um último clamor pela identidade, por algo que the individualizasse nessa abertura ao corpofenda, uma resistência à inoperância da comunidade. Assim, a comunidade permanece por vir, permanece fora dos limites da obra, sem realizar-se, cumprindo sua vocação de incompletude.

Ao analisar o volume Ó, de Nuno Ramos, Luciana Sastre (2015) identifica, em sua linguagem, uma "matéria sonora que não nomeia nada". Assim também poderíamos descrever os textos do Monólogo e de Junco, pois estes últimos não são legenda para as imagens, mas singularidades contíguas, que tocam os limites das existências umas das outras. Pois a arte diz, à sua maneira, o indizível, situa-se na borda e toca o limite do desejo, do eu, do outro. É o espaço de um encontro possível, de uma comunicação para além do logos, espaço da configuração de um ser-em-comum. Nancy, ainda, nos ensina que a arte é uma possibilidade e uma potência de imposição da vida, do desamparo da vida, frente ao poder. E nada mais desamparado que o cadáver de um cachorro abandonado na beira de uma rodovia de alto fluxo. Maria Rita Kehl, em O tempo e o cão (2009), escreve que o atropelamento de um cão numa rodovia a levou a parar, a considerar o tempo da vida, arrancado à vida pelo tempo do capital. Também o tempo em que habita a voz poética de Monólogo é suspenso em seu encontro com o cachorro (ainda que que o artista, no vídeo, 
não se detenha - entra no carro e vai embora, deixando apenas o cão e o poema): “Meu interesse é que não morre. Meu interesse gruda aqui, exatamente aqui, o meu olhar fixo, cavado" (Ramos 2007: 359).

Retomando a primeira frase do texto disponibilizado seja no site, seja no livro Ensaio geral - "Poesia (pausa), entre nós dois" -, deparamo-nos com a dupla separação disso, a poesia, que se interpõe entre aquele que diz eu e o cachorro para o qual o texto se destina: há uma marcação performativa, a rubrica "(pausa)", além de um sinal gráfico, a virgula, cuja presença não é exigida por qualquer ordenamento gramatical. A separação se inscreve, assim, em dois regimes, o auditivo/performativo, destinado, primeiramente, ao cachorro; e o visual/legível, destinado àqueles que veem/leem o texto. A foto abaixo, disponibilizada no site do artista, permite visualizar que, se a legibilidade do texto é dificultada pela proximidade das placas de mármore, esse breve trecho é, no entanto, legível.

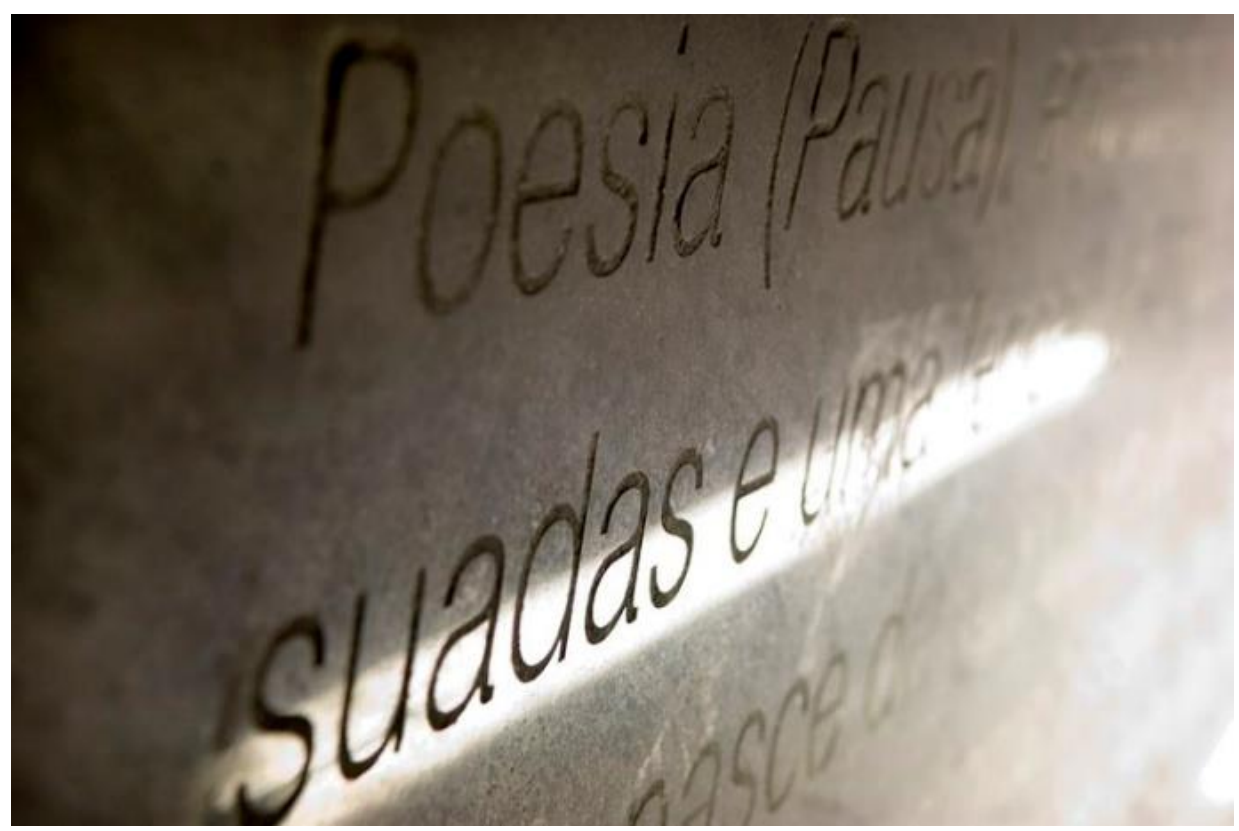

Figura 4. Fonte: www.nunoramos.com.br

Assim, é interessante que paremos nessa dupla pausa: uma performativa e outra gráfica. Um silêncio que ressoa e uma marca que fere a página (ou o mármore). Aquilo que se coloca entre quem escreve/fala e quem lê/ouve não apenas é o que primeiro se oferece do texto, separando-nos do que seguirá - "entre nós dois" - , mas é também uma 
insistência, um relevo, uma remissão. É a poesia que inaugura esse espaço em que se encontrarão homem e cachorro, em que nos encontraremos com o objeto artístico. É a poesia que nos chama, nos convoca.

Há, no entanto, na performance, um deslocamento significativo: no vídeo, ouvimos o artista dizer "entre nós dois, poesia". Em primeiro lugar, essa inversão, quando escrita, motiva o emprego da vírgula, da incisão que separa o chamado daqueles a quem convoca. Esse desvio em relação ao texto escrito, único afastamento do texto disponibilizado no site (seja em relação às palavras que o compõem, seja em relação às rubricas que indicam a performance), coloca em primeiro plano "nós dois", esses corpos-fenda que responderão ao chamado da poesia e instaurarão um espaço-entre no qual o texto possa ressoar.

Dessa forma, temos duas versões do texto que, por um lado, erigem a separação entre o que se lê/escreve e o que se ouve/fala, enquanto, por outro lado, tais versões trazem para a construção verbal a falta de identificação que está no centro da comunidade ilegível estabelecida entre homem e cachorro.

Se a poesia é, portanto, o chamado que convoca, artista, cachorro, espectadoras e espectadores, à construção de uma comunidade em devir, que inclua as singularidades nas quais não nos reconhecemos (humano $x$ não-humano / vivente $x$ não-vivente), a poesia também ocupa um lugar instável, não fixado.

Sobre essa comunidade inoperante, Nancy escreve que

Somos semelhantes porque estamos, cada um, expostos ao fora que somos nós para nós-mesmos. 0 semelhante não é o parecido. Não me encontro, nem me reconheço no outro: padeço a, ou sua, alteridade, e a, ou sua, alteração, que "em mim mesmo" põe minha singularidade fora de mim, e que a finaliza infinitamente. A comunidade é o regime ontológico singular no qual o outro e o mesmo são o semelhante: vale dizer, a divisão da identidade (Nancy 2000: 44)

Nesse singularizar-se fora de si, o poema que abre o livro Junco parece borrar os limites entre voz poemática e cachorro morto, ao dizer: "Cachorro morto num saco de lixo / areia, sargaço, cacos de vidro / mar dos afogados, mar também dos vivos / escuta teu murmúrio no que eu digo" (Ramos 2011: 11). 
O murmúrio do cachorro morto, ou o do mar - de qualquer forma, daquilo que não é humano, ou ser vivente - é o murmúrio da finitude, presente em todos os existentes. 0 som, como já dito anteriormente, se constitui de remissões, de ressonâncias: de um relacionamento com o que o cerca, mas também consigo mesmo. Soar, escreve Nancy, "é vibrar em si mesmo ou por si mesmo: para o corpo sonoro, não é só emitir um som, mas estender-se, trasladar-se e resolver-se efetivamente em vibrações que, ao mesmo tempo, o relacionam consigo e o põem fora de si" (Nancy 2007: 20). O corpo que diz, que ressoa, é sempre ao mesmo tempo o corpo do ouvinte.

Assim, o som na beira da estrada ressoa por esse ambiente hostil, instaura um lugar entre os sons das máquinas (de morte?) que cortam o espaço sem se aperceber do cachorro morto. "Permito que o carro passe. Permito o vento, a buzina" (Ramos 2007: 359). O som do monólogo inaugura um espaço (o espaço de sua ressonância) que não exclui o entorno, e o ressignifica, incluindo-o no tempo de sua presença, no tempo de sua performance, abrindose para a alteridade desse tempo-espaço que se suporia alheio à voz poemática.

Muitos são os deslocamentos operados na criação e na circulação da instalação: um texto é lido, a leitura é gravada, a gravação é reproduzida para um cachorro morto numa via pública, a imagem da reprodução da gravação para o cachorro é filmada em vídeo, o vídeo é projetado em exposição, a exposição é fotografada, as fotos são comentadas em ensaios analíticos... Cada deslocamento atrai interferências - produzindo detritos e de detritos se alimentando, estabelecendo transposições e de transposições se abastecendo.

Cada deslocamento soma ao objeto uma nova camada de ilegibilidade. E cada ilegibilidade propicia aberturas a um impensado que emerge a partir daí, somente a partir da daí. A ilegibilidade se torna então uma fenda - local de passagem e, antes até, de nascimento. Um corpo-fenda: aquilo que retém resíduos, a custo de se infeccionar ou, melhor, de se intensificar.

Assim como os limites com o entorno, os limites entre a voz poemática e o cachorro se borram, se desvanecem, se reconfiguram. Também em Junco, mais um dos deslocamentos que atuam nesse projeto, homem e cachorro parecem confundir-se num corpo inaugurado no poema: "Meus ossos, meus passos / restos de um cão grudado / no asfalto aceso pela cal / incandescente do dia" (Ramos 2011: 21). E a própria literatura, essa 
forma de comparecimento, se oferece ao vivente humano como forma de ir em direção a esse outro extremo que é o não-humano e não-vivente: "A mim foi dado: passo e peso / fole pulmonar, grito / mãos para cardar / como a um peixe seu chocalho / de espinhas. Não foi para ceder / à carniça / mas para amar que me foi dado" (idem: 45). Pois o amor é, antes de mais nada, encontro, contaminação. E a linguagem nos convoca a ocupar o espaço-entre desse chamado.

No poema seguinte, o eu parece saber que a ressonância e o sentido da voz está muito além de seu significado imediato, pois se recusa a amar com palavras, a amar vendo: “Mas sem palavras serei / distinto e contíguo / ao batimento aqui cardíaco -" (idem: 47). Ou seja, ressoa, aqui, a alegria do esquecimento dos nomes.

Mas não deixa de ressoar, também, a angústia que é, para a voz do Monólogo, a impossibilidade da contenção e do reconhecimento de sentido que cabem no nome. Ainda que assuma a comunidade apenas possível na finitude que os habita, ao preparar-lhe um funeral, tal assunção não lhe impede de imaginar-se na mesma situação: atropelado na beira da estrada. E ainda a angústia do nome não o abandona pois, ao questionar o cachorro por seu funeral, pergunta: “Que nome você daria? Qual meu nome, cachorro?” (Ramos 2007: 362).

Novamente, em Junco, encontramos um texto que parece dialogar diretamente com o trecho acima, no qual se afirma que "O que de mim se ama / não sou eu, é esse nome" (Ramos 2011: 99). A angústia do nome - que comparece no reconhecimento de um amor que se detém na identificação do nome, um amor que não ex-põe o amante à contaminação do corpo-fenda - é, também, angústia por uma recusa da restrição imposta pelo nome, pois a voz poemática já não cabe no nome ou na humanidade com a qual é reconhecida. Dessa forma, continua o poema, o que dele se ama (o que exige que dele se ame) é, para além do nome, "baque surdo / tique / taque / que roda aqui, ó (eu mostro) / bem aqui, ó / redondo sob a blusa / pá escavadeira (eu mostro) / cavando / o peito pântano onde dormem / troncos sólidos e cachorros mortos" (ibidem). Vemos, aqui, um processo de criação que amplia o nome. De delimitação, nome próprio, identidade, passamos à inespecificidade do som, do ruído, do murmúrio ("baque surdo / tique / taque") que encontra a alteridade e a 
comunidade para além do vivente ("o peito pântano onde dormem / troncos sólidos e cachorros mortos").

Por fim, cabe recordar mais uma vez Nancy:

Não é o espaço do corpo à escuta, por sua vez, também uma coluna oca sobre a qual se tensiona uma pele, mas desde a qual, ao mesmo tempo, a abertura de uma boca pode retomar e relançar a ressonância? Golpe de fora, clamor de dentro, esse corpo sonoro, sonorizado, se põe à escuta simultânea de um "si mesmo" e de um "mundo" que estão em ressonância um com o outro. Se angustia (se encolhe) e se regozija (se dilata) por isso. Se escuta angustiar-se e regozijar-se, goza e se angustia com essa escuta mesma em que o distante ressoa muito próximo. (Nancy 2007: 87)

Parecendo ecoar (ressoar) as palavras do filósofo, o poema 41 de Junco encontra um lugar de escuta simultânea de si e do mundo (mundo esse que não pode excluir o cachorro morto e o tronco podre): "Nunca houve / vácuo, nunca um / nada vago // varou a forma que uma ruga / não enchesse / logo de pele. // Tudo é cheio / grudado ao vizinho / o ovário sozinho // viaja no rádio. / Dizemos ó / e nosso corpo // expande a baía / badala a amídala / de um sino contínuo // - um sol gelatina que enche a retina / não de luz, mas de fala" (Ramos 2011: 103).

Esse corpo que se preenche (de outro?), se expande na emissão da voz - "dizemos ó" - , não da palavra, mas do sentido apenas possível que habita a interjeição. E a retina se enche "não de luz", não daquilo que permite a leitura, a palavra, o logos, mas do som que é, antes demais nada, ressonância, ou seja, relação e, talvez, comunidade. 


\section{Bibliografia}

Giorgi, Gabriel (2016), Formas comuns. Animalidade, literatura, biopolítica, tradução de Carlos Nougué, Rio de Janeiro, Rocco.

Kehl, Maria Rita (2009), O tempo e o cão, A atualidade das depressões, São Paulo, Boitempo. Nancy, Jean-Luc (2007), A la escucha, tradução de Horacio Pons, Buenos Aires, Amorrortu. -- (2000) La comunidad inoperante, tradução de Juan Manuel Garrido Wainer, Santiago de Chile, Escuela de Filosofía Universidad ARCIS.

Ramos, Nuno (site do artista), <www.nunoramos.com.br> (último acesso em 14/04/2017).

-- (2007), “Monólogo para um cachorro morto”, in Ensaio geral, São Paulo, Globo, 359-363.

-- (2011), Junco, São Paulo, lluminuras.

Sastre, Luciana (2015), “Escritura performática de los encuentros. Notas sobre Ó, de Nuno Ramos”, trabalho apresentado no Coloquio Internacional “¿Por qué Brasil, qué Brasil? Recorridos y prácticas críticas desde Argentina". Universidad Nacional de Córdoba, Manuscrito.

Rafaela Scardino é doutora em Letras e professora do Departamento de Línguas e Letras da Universidade Federal do Espírito Santo. É autora de Movimentos de demolição: deslocamentos, identidades e literatura (2011) e coorganizadora de Traços de um outro mapa: literatura contemporânea nas Américas (2013). 